\title{
PEMBELAJARAN TEMATIK DAN BERMAKNA DALAM PERSPEKTIF REVISI TAKSONOMI BLOOM
}

\author{
Nur Fajriana Wahyu Ardiani, Nanda Adi Guna, Reni Novitasari, dan Ridwan Prihantono \\ Mahasiswa Magister Manajemen Pendidikan FKIP Universitas Kristen Satya Wacana
}

\begin{abstract}
ABSTRAK
Revisi Taksonomi Bloom yang terdiri dari dua dimensi baru yaitu dimensi proses kognitif dan dimensi pengetahuan. Dalam dimensi pengetahuan terdapat empat aspek pengetahuan, salah satunya adalah pengetahuan metakognitif yang berarti "beyond thinking" sebagai sesuatu yang ada di atas berpikir itu sendiri. Dimensi yang kedua adalah dimensi proses kognitif yang mana terdapat 6 kategori didalamnya, yaitu mengingat, memahami, menerapkan, menganalisa, mengevaluasi dan mencipta. Dimensi pengetahuan dan proses kognitif menjadi syarat utama dalam pembelajaran tematik dan bermakna. Ketika seseorang mampu menerapkan pembelajaran tematik maka dimungkinkan terjadinya pembelajaran bermakna yang utuh sesuai dengan tahap perencanaan, penerapan dan evaluasi.
\end{abstract}

Kata kunci: revisi taksonomi Bloom, metakognisi, pembelajaran bermakna, tematik

\section{PENDAHULUAN}

Berpikir dianggap sebagai suatu proses kognitif, suatu aktivitas mental untuk memperoleh pengetahuan. Kemampuan berpikir menurut taksonomi bloom diatur ke dalam enam tingkatan, yaitu dari yang terendah (knowledge) hingga yang tertinggi (evalution). Tujuan ranah kognitif berhubungan dengan ingatan atau pengenalan terhadap pengetahuan dan informasi serta pengembangan keterampilan intelektual. Aktual tetapi, pada tahun 2001 Anderson dan Krathwohl merevisi taksonomi bloom dengan mengkombinasi proses kognitif dan dimensi pengetahuan. Perbedaan taksonomi bloom yang original dengan hasil revisi Anderson dan Krathwohl terletak pada istilah (term) dan penekanannya (emphasis). Namanama dari kategori diubah dari kata benda (noun) menjadi kata kerja (verb) yang lebih akurat dan mencerminkan adanya proses berpikir secara aktif.

Salah satu dimensi pengetahuan dalam revisi taksonomi bloom terdapat pengetahuan metakognitif. Pengetahuan metakognitif adalah pengetahuan mengenai pengertian umum maupun kesadaran dan berpikir, berpikir tentang apa yang dipikirkan dan bagaimana proses berpikirnya. Secara sederhana ada dua aspek dari metakognisi yaitu refleksi-berpikir tentang apa yang kita ketahui dan pengaturan diri mengelola bagaimana kita belajar. Di samping itu terdapat enam kategori dimensi proses kognitif dalam revisi taksonomi bloom yaitu mengingat, memahami, menerapkan, menganalisa, mengevaluasi, dan mencipta. Proses kognitif tersebut, merupakan syarat terjadinya pembelajaran tematik. Pembelajaran tematik merupakan pembelajaran terpadu yang menggunakan tema untuk mengaitkan beberapa mata pelajaran sehingga dapat memberikan pengalaman bermakna kepada siswa sehingga membuka peluang yang sangat besar untuk penciptaan situasi belajar bermakna. Dimana guru bertindak sebagai fasilitator dan motivator sementara siswa aktif membangun pengetahuannya berdasarkan serangkaian kegiatan pembelajaran yang dilakukan. Selain itu, siswa mampu memecahkan permasalahan 
dan belajar secara aktif, bahkan merumuskan suatu rumusan menggunakan menggunakan kata-kata sendiri.

Saat ini, pembelajaran tematik menjadi fenomena tersendiri dalam pendidikan kita. Pemerintah berharap pembelajaran tematik sebagai pembelajaran di era mendatang, sehingga pemerintah mengharapkan pendidikan di Indonesia menerapkan pendekatan pembelajaran tematik. Oleh karena itu artikel ini dibuat untuk membantu pembaca dalam memahami pembelajaran tematik dan bermakna melalui revisi taksonomi bloom.

\section{Taksonomi Bloom}

Taksonomi berasal dari bahasa Yunani tassein berarti untuk mengklasifikasi dan nomos yang berartiaturan. Taksonomi berarti klasifikasi berhirarki dari sesuatu atau prinsip yang mendasari klasifikasi. Semua hal yang bergerak, benda diam, tempat, dan kejadian sampai pada kemampuan berpikir dapat diklasifikasikan menurut beberapa skema taksonomi (http://id.wikipedia.org/wiki/ Taksonomi).

Konsep Taksonomi Bloom dikembangkan pada tahun 1956 oleh Benjamin Bloom dkk. Konsep ini mengklasifikasikan tujuan pendidikan dalam tiga ranah, yaitu kognitif, afektif dan psikomotorik. Ranah kognitif meliputi fungsi memproses informasi, pengetahuan dan keahlian mentalitas. Ranah afektif meliputi fungsi yang berkaitan dengan sikap dan perasaan. Sedangkan ranah psikomotorik berkaitan dengan fungsi manipulatif dan kemampuan fisik

Ranah kognitif menggolongkan dan mengurutkan keahlian berpikir yang menggambarkan tujuan yang diharapkan. Proses berpikir mengekspresikan tahap-tahap kemampuan yang harus siswa kuasai sehingga dapat menunjukan kemampuan mengolah pikirannya sehingga mampu mengaplikasikan teori ke dalam perbuatan. Mengubah teori ke dalam keterampilan sehingga dapat meng- hasilkan sesuatu yang baru sebagai produk inovasi pikirannya. Memahami sebuah konsep berarti dapat mengingat informasi atau ilmu mengenai konsep itu. Seseorang tidak akan mampu mengaplikasikan ilmu dan konsep jika tanpa terlebih dahulu memahami isinya.

\section{Revisi Taksonomi Bloom}

Konsep taksonomi Bloom mengalami perbaikan seiring dengan perkembangan dan kemajuan jaman serta teknologi. Salah seorang murid Bloom yang bernama Lorin Anderson merevisi taksonomi Bloom pada tahun 1990. Hasil perbaikannya dipublikasikan pada tahun 2001 dengan nama Revisi Taksonomi Bloom.

Dalam Taksonomi asli, kategori pengetahuan diwujudkan baik aspek kata benda dan kata kerja. Aspek kata benda atau subjek ditentukan dalam subkategori luas pengetahuan itu. Aspek kata kerja termasuk dalam definisi yang diberikan kepada pengetahuan bahwa siswa diharapkan dapat mengingat atau mengenali pengetahuan. Hal ini menyebabkan kategori pengetahuan menjadi ambigu atau bermakana ganda. Maka dari itu pada taksonomi bloom versi Anderson dkk merevisinya menjadi dua aspek: kata benda dan kata kerja untuk membentuk dimensi yang terpisah. Kata benda menyediakan dasar untuk dimensi pengetahuan dan kata kerja membentuk dasar untuk dimensi proses kognitif. Perubahan dari kerangka pikir asli ke revisinya diilustrasikan pada gambar 1 .

Berdasarkan gambar 1, dapat diketahui perubahan taksonomi dari kata benda (dalam taksonomi Bloom) menjadi kata kerja (dalam taksonomi revisi). Perubahan ini dibuat agar sesuai dengan tujuan-tujuan pendidikan. Tujuan-tujuan pendidikan mengindikasikan bahwa siswa akan dapat melakukan sesuatu (kata kerja) dengan sesuatu (kata benda). Kategori pengetahuan dalam taksonomi Bloom berubah menjadi mengingat. Bentuk kata kerja mengingat mendeskripsikan tindakan yang tersirat dalam kategori pengetahuan aslinya; 
tindakan pertama yang dilakukan oleh siswa dalam belajar pengetahuan adalah mengingatnya. Kategori pemahaman menjadi memahami. Pemahaman merupakan tingkat memahami yang paling rendah. Pemahaman terbatas pada hanya memahami tentang apa yang sedang dikomunikasikan tanpa menghubungkannya dengan materi lain. Perubahan dari pemahaman menjadi memahami karena dalam pemilihan nama-nama kategori, mempertimbangkan keluasan pemakaian istilah tersebut oleh banyak guru.

Kategori aplikasi menjadi mengaplikasikan. Dalam kategori ini hanya terjadi perubahan dari kata benda menjadi kata kerja. Kategori analisis menjadi menganalisis. Dalam kategori ini hanya terjadi perubahan dari kata benda menjadi kata kerja. Kategori sintesis menjadi mencipta. Mencipta melibatkan proses menyusun elemen-elemen menjadi sebuah kesatuan yang koheren dan fungsional yang akhirnya dapat menghasilkan sebuah produk baru yang belum pernah ada sebelumnya. Sintesis hanya terbatas pada memadukan elemen-elemen dan bagian-bagian untuk membentuk satu kesatuan dengan melibatkan proses mengolah potongan-potongan, bagianbagian, elemen-elemen dan mengatur serta memadukan sedemikian rupa sehingga membentuk sebuah pola atau struktur yang sebelumnya tidak jelas. Kategori evaluasi menjadi mengevaluasi. Dalam kategori ini hanya terjadi perubahan dari kata benda menjadi kata kerja.

Urutan sintesis dan evaluasi ditukar. Taksonomi revisi mengubah urutan dua kategori proses kognitif dengan menempatkan mencipta sebagai kategori yang paling kompleks. Kategori-kategori pada taksonomi Bloom disusun menjadi sebuah hierarki kumulatif yang berarti penguasaan kategori yang lebih kompleks mensyaratkan penguasaan semua kategori di bawahnya yang kurang kompleks. Penelitian-penelitian kemudian memberikan bukti-bukti empiris bahwa hierarki kumulatif hanya berlaku pada tiga kategori tengahnya yakni pemahaman, aplikasi, dan analisis, tetapi tidak pada dua kategori terakhir (sintesis dan evaluasi). Penelitian membuktikan sintesis merupakan kategori yang lebih kompleks daripada evaluasi. Adapun penjelasan mengenai masing-masing dimensi proses kognitif disajikan pada tabel 1 .

Dimensi pengetahuan tetap dipertahankan dalam taksonomi revisi namun berubah menjadi dimensi tersendiri karena diasumsikan bahwa setiap kategori-kategori dalam taksonomi membutuhkan pengetahuan sebagai apa yang harus dipelajari oleh siswa. Penjelasan lebih lanjut mengenai dimensi pengetahuan ditunjukkan melalui tabel 2.

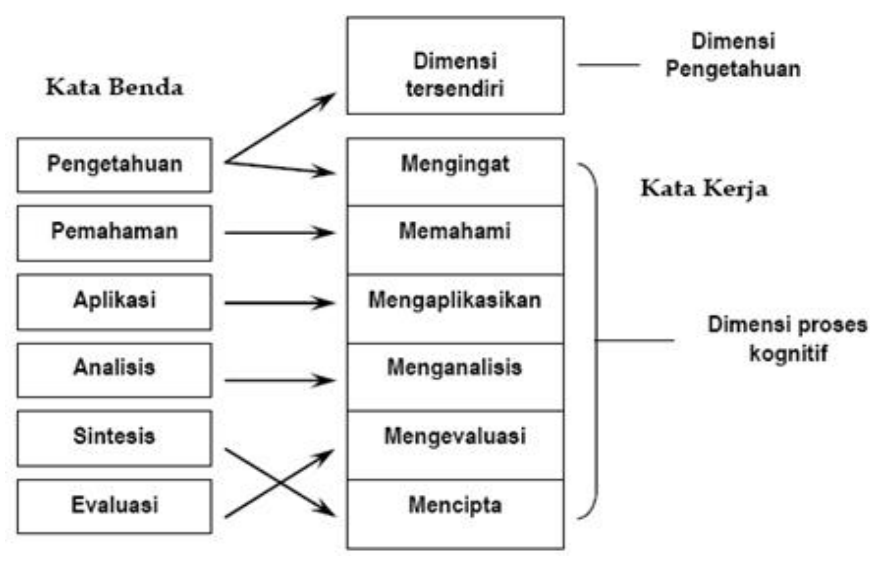

Gambar 1. Perubahan dari Kerangan Pikir Asli ke Revisi

Sumber: Anderson dan Krathwohl, 2010 


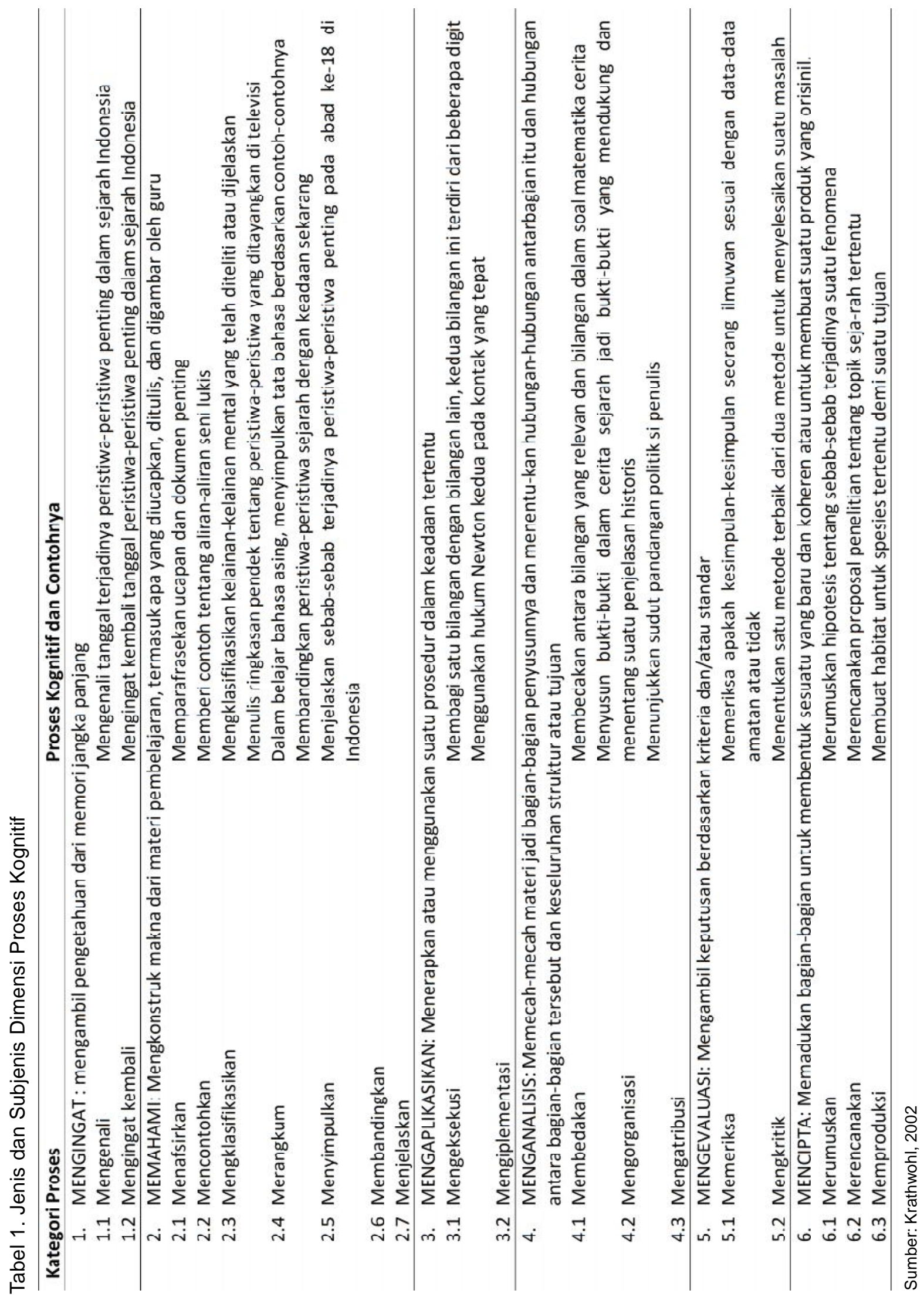


Tabel 2. Jenis dan Subjenis Dimensi Pengetahuan

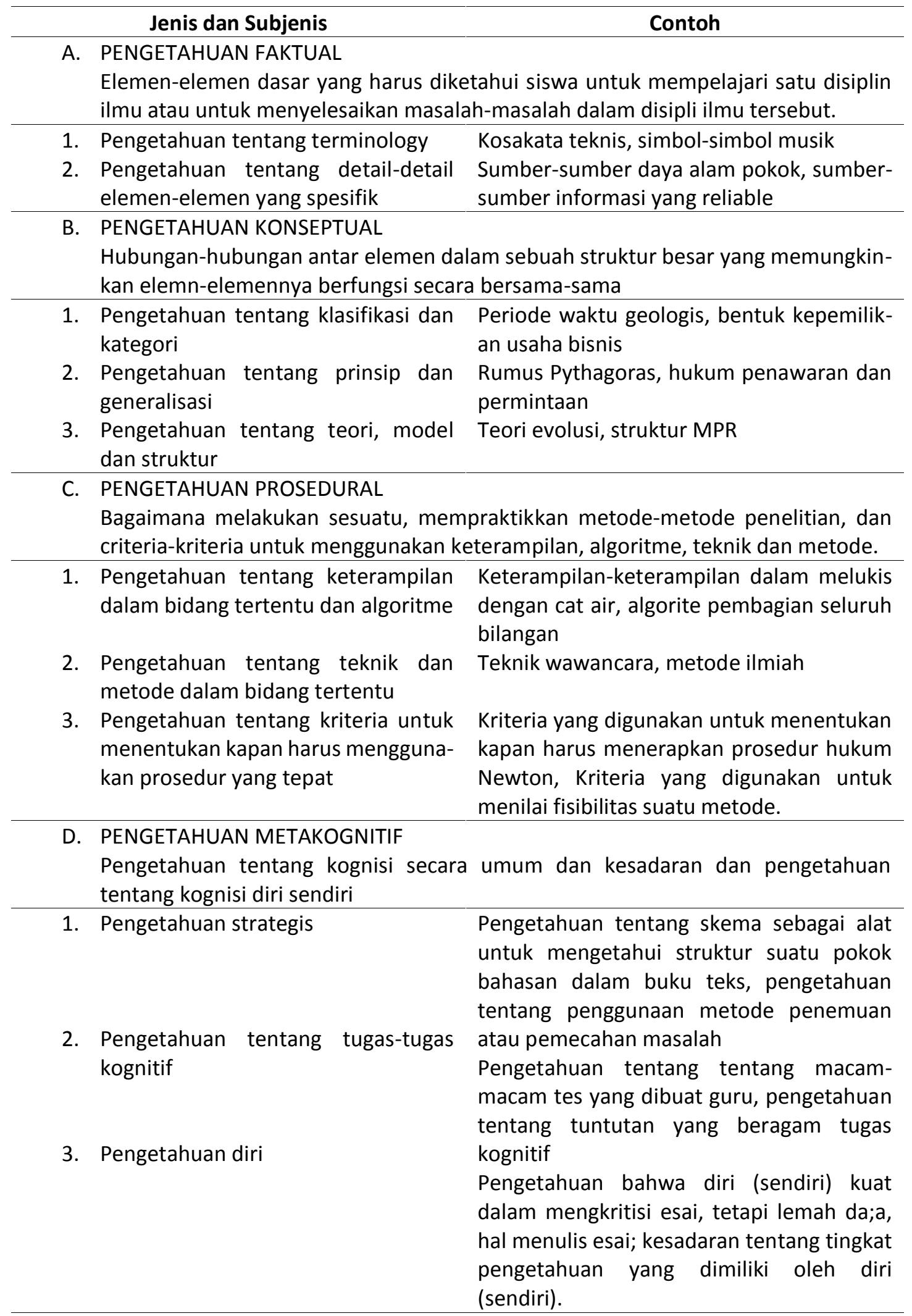

Sumber: Krathwohl: 2002 
Konsep-konsep pembelajaran yang berkembang terfokus pada proses-proses aktif, kognitif dan konstruktif dalam pembelajaran yang bermakna. Pembelajar diasumsikan sebagai pelaku yang aktif dalam aktivitas belajar; mereka memilih informasi yang akan mereka pelajari, dan mengonstruksi makna berdasarkan informasi. Ini merupakan perubahan dari pandangan pasif tentang pembelajaran ke pandangan kognitif dan konstruktif yang menekankan apa yang siswa ketahui (pengetahuan) dan bagaimana mereka berpikir (proses kognitif) tentang apa yang mereka ketahui ketika aktif dalam pembelajaran. Dalam ranah kognitif yang telah direvisi Anderson dan Krathwohl (2001:66-88) meliputi mengingat (remember),memahami/mengerti (understand), menerapkan (apply), menganalisis (analyze), mengevaluasi (evaluate), dan menciptakan (create). Dimensi pengetahuan berisikan empat kategori yaitu faktual, konseptual, prosedural, dan metakognitif. Kedua dimensi tersebut dapat digabung dalam sebuah tabel taksonomi seperti pada tabel 3 .

Tabel taksonomi diharapkan bisa berperan dalam membantu mengatasi permasalahan tersebut. Seperti yang diungkapkan Anderson (2010: 143) tabel taksonomi berguna bagi guru untuk: 1) membantu lebih memahami tujuan-tujuan pembelajaran mereka; 2) dengan memahami tujuan-tujuan pembelajaran mereka, guru dapat menggunakan tabel taksonomi untuk membuat keputusan-keputusan yang lebih bagus mengenai bagaimana mengajar dan menilai siswa dalam kerangka tujuan-tujuan pembelajaran itu; 3) membantu guru menentukan seberapa sesuai antara tujuan, asesmen, dan pembelajarannya dengan cara yang tepat. Adanya dua dimensi pada tabel taksonomi membantu dalam proses menyatakan tujuan dan perencanaan; mengarahkan kegiatan pembelajaran menjadi lebih tajam; lebih jelas dalam mendefinisikan asesmen serta hubungan yang lebih kuat pada asesmen terhadap tujuan dan pembelajaran. Langkah penggunaan tabel taksonomi (Anderson, 2010:46):

1. Rumuskan tujuan pembelajaran dengan kata kerja dan kata benda. Untuk memudahkan merumuskan kata kerja bisa dilakukan dengan mencermati 19 proses kognitif (lihat tabel 1). Untuk kata benda bisa dilakukan dengan mencermati sub-sub jenis pengetahuan (lihat tabel 2).

2. Kemudian letakkan tujuan pembelajaran pada tabel taksonomi sesuai dengan kategorinya.

Tabel 3. Taksonomi Dua Dimensi

\begin{tabular}{|c|l|l|l|l|l|l|}
\hline $\begin{array}{c}\text { Dimensi } \\
\text { Pengetahuan }\end{array}$ & Mengingat & Memahami & Menerapkan & Menganalisis & Mengevaluasi & Mencipta \\
\hline $\begin{array}{c}\text { Pengetahuan } \\
\text { Faktual }\end{array}$ & & & & & \\
\hline $\begin{array}{c}\text { Pengetahuan } \\
\text { Konseptual }\end{array}$ & & & & & & \\
\hline $\begin{array}{c}\text { Pengetahuan } \\
\text { Prosedural }\end{array}$ & & & & & \\
\hline $\begin{array}{c}\text { Pengetahuan } \\
\text { Metakognitif }\end{array}$ & & & & & \\
\hline
\end{tabular}

Sumber: Krathwohl, 2002 
3. Setelah tujuan pembelajaran "terpasang" pada tabel taksonomi, langkah berikutnya yang dilakukan adalah merancang kegiatan pembelajaran yang akan dilakukan siswa untuk mencapai tujuan pembelajaran tersebut. Tuliskan pada tabel taksonomi.

Setelah tujuan dan kegiatan pembelajaran dituliskan, langkah selanjutnya adalah merancang asesmen atau penilaian yang akan digunakan. Sudah dikatakan di awal bahwa antara tujuan pembelajaran, kegiatan pembelajaran, dan penilaiannya harus selaras untuk mencapai pembelajaran yang baik. Jangan sampai terjadi masalah seperti misalnya guru merumuskan tujuan pembelajaran: menganalisis sebab terjadinya suatu peristiwa namun kemudian menguji siswanya dengan tes memori faktual. Asesmen di sini bisa berfungsi untuk mengetahui tingkat ketercapaian tujuan pembelajaran, atau bisa juga untuk acuan dalam memperbaiki proses kegiatan belajar selanjutnya.

\section{Metakognitif}

Metakognitif menurut Margaret W. Matlin adalah "knowledge and awareness about cognitive processes - or our thought about thinking”). Sehingga metakognitif dapat juga diartikan sebagai sesuatu yang ada diatas berpikir itu sendiri. Pengetahuan metakognitif adalah pengetahuan tentang kognisi secara umum dan kesadaran dan pengetahuan tentang kognisi itu sendiri. Pengetahuan metakognitif ini memiliki tiga bagian, yaitu:

Pengetahuan strategis: pengetahuan tentang skema sebagai alat untuk mengetahui struktur suatu pokok bahasan dalam buku teks, pengetahuan tentang penggunaan metoda penemuan atau pemecahan masalah. Bisa disebut juga bahwa pengetahuan strategis adalah strategi umum untuk belajar, berpikir, dan pemecahan masalah, contohnya memecahkan persamaan kuadrat. Pengetahuan strategis berguna untuk beberapa hal misalnya meng- hafal materi, mengambil makna dari teks, memahami yang didengar/dibaca.

Pengetahuan tentang tugas-tugas kognitif: pengetahuan tentang macam-macam tes yang dibuat guru, pengetahuan tentang tuntutan be-ragam tugas kognitif. Pengetahuan tentang tugas mencakup pengetahuan bahwa tugas yang berbeda dapat lebih sulit atau lebih mudah dan mungkin memerlukan strategi kognitif yang berbeda. Misalnya, tugas untuk mengingat kembali atau mereview pastinya akan lebih berat untuk dilakukan daripada hanya sekedar pengenalan suara semata. Hal ini karena membuka dan mencari sesuatu pada otak kita lebih susah daripada hanya sekedar menerka jawaban mana yang benar pada soal pengenalan suara. Sehinga siswa mampu untuk memilih strategi yang sesuai dengan situasi dan kondisi yang berbeda serta menentukan penggunaan strategi yang paling tepat guna menyelesaikan tugas-tugas mereka.

Pengetahuan diri: pengetahuan bahwa diri (sendiri) kuat dalam mengkritisi esai, tetapi lemah dalam menulis esai, kesadaran tentang tingkat pengetahuan yang dimiliki oleh diri sendiri. Jika seseorang mempunyai pengetahuan ini maka mereka bisa tahu ketika mereka tidak tahu sesuatu dan harus bergantung pada beberapa strategi umum untuk menemukan informasi yang tepat. Selain pengetahuan diri secara umum, individu juga memiliki keyakinan tentang motivasi mereka. Hal ini mempengaruhi penilaian mereka terhadap kemampuan diri sendiri untuk melakukan tugas (selfefficacy), tujuan mereka untuk menyelesaikan tugas (belajar atau hanya mendapatkan nilai yang baik), dan ketertarikan dan nilai tugas mereka (ketertarikan yang tinggi dan bernilai tinggi berlawanan dengan ketertarikan rendah dan nilai rendah).

Aspek penting lain dari pengetahuan kondisional menyangkut situasi lokal dan secara umum norma-norma sosial, konvensional, dan norma-norma budaya untuk meng- 
gunakan strategi yang berbeda. Sebagai contoh, guru dapat mendorong penggunaan strategi tertentu untuk membaca. Seorang mahasiswa yang mengetahui pilihan strategi guru lebih mampu beradaptasi dengan tuntutan guru kelas ini. Dalam cara yang sama, budaya yang berbeda mungkin memiliki norma-norma untuk menggunakan strategi yang berbeda dan cara berpikir tentang masalah. Sekali lagi, mengetahui norma-norma ini dapat membantu siswa beradaptasi dengan tuntutan budaya dalam hal memecahkan masalah.

Semua hal di atas sangatlah berkaitan dengan dikembangkannya pembelajaran tematik yang saat ini digadang-gadang akan menjadi jenis pembelajaran di era mendatang guna menciptakan siswa yang lebih terampil dan lebih mampu bersaing dengan siswa-siswa di negara lain.

\section{Pembelajaran Tematik}

Pembelajaran dengan pendekatan tematik adalah pembelajaran yang pendekatan pengembangannya dimulai dengan menentukan tema tertentu (Trianto, 2010: 45). Sedangkan menurut Sukayati (2009:13) pembelajaran tematik merupakan suatu pendekatan dalam pembelajaran yang secara sengaja mengaitkan atau memadukan beberapa Kompetensi Dasar (KD) dan indikator dari Standar Isi dari beberapa mata pelajaran menjadi satu kesatuan untuk dikemas dalam satu tema. Dengan adanya kaitan tersebut maka siswa akan dapat memahami konsep-konsep yang saling terkait dari beberapa mapel yang sesuai dengan kebutuhan dan perkembangan siswa. Hal ini sesuai dengan karakteristik pembelajaran tematik, yaitu (Tim Puskur dalam Sukayati, 2009:14):

1. Pembelajaran berpusat pada peserta didik.

2. Memberikan pengalaman langsung kepada anak.

3. Pemisahan mapel tidak kelihatan atau antar mapel menyatu.
4. Menyajikan konsep dari berbagai mapel dalam suatu proses pembelajaran sehingga bermakna.

Menurut Tim Puskur (Sukayati, 2009:16) dalam melaksanakan pembelajaran tematik ada beberapa rambu-rambu yang perlu diperhatikan:

1. Tidak semua mapel dapat dipadukan atau dikaitkan.

2. KD yang tidak dapat dipadukan atau diintegrasikan jangan dipaksakan untuk dipadukan.

3. KD yang tidak tercakup pada tema tertentu harus tetap diajarkan baik melalui tema lain maupun disajikan secara mandiri

4. Tema-tema yang dipilih disesuaikan dengan karakteristik siswa, minat, lingkungan, daerah setempat.

Adapun langkah-langkah dalam menyiapkan pembelajaran tematik menurut Sukayati (2009:20) adalah:

\section{Memetakan KD}

Langkah pertama adalah menjabarkan SK dan KD ke dalam indikator. Kemudian identifikasi dan analisis untuk setiap SK, $\mathrm{KD}$, dan indikator yang cocok untuk suatu tema sehingga semua SK, KD, dan indikator terbagi habis. Namun jangan memaksakan diri, jika ada KD yang tidak mungkin digabungkan, karena bila dipaksakan akan sulit mencapai tujuan kompetensi yang diharapkan. KD dari setiap mapel yang tidak bisa dikaitkan dalam satu tema bisa diajarkan secara mandiri, di luar tema.

2. Menentukan tema

Tentukan satu tema yang dapat mempersatukan KD dan indikator dari beberapa mapel. Tema yang dipilih sebaiknya tidak asing bagi kehidupan peserta didik baik di rumah maupun di sekolah. Dalam menentukan tema ini ada dua cara yang bisa digunakan (Hastomo dan Senen, dalam sosialisasi KTSP):

1) Cara Pertama, mempelajari SK dan KD yang terdapat dalam tiap mapel, kemu- 
dian baru dilanjutkan dengan menentukan tema yang sesuai.

2) Cara Kedua, menetapkan terlebih dahulu tema-tema pengikat keterpaduan, baru kemudian dipilih KD dan indikator yang bisa dikaitkan dengan tema tersebut.

3. Menyusun jaringan tema

Menyusun jaringan tema berarti memadukan beberapa KD dari mapel-mapel yang sesuai dengan tema yang dipilih. Dengan adanya jaringan tema ini akan terlihat kaitan antara tema yang dipilih dengan KD dari beberapa mapel yang disatukan.

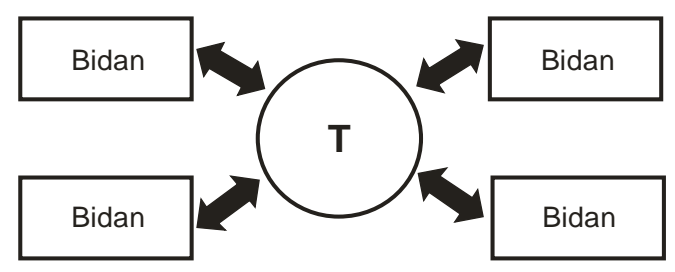

Gambar 2. Diagram pembelajaran tematik

Setelah jaringan tema tersusun, guru bisa mulai melanjutkan dengan membuat sketsa pembelajaran. Namun, tidak sedikit praktisi pendidikan yang masih mengalami kesulitan dalam menyelaraskan antara rumusan tujuan, kegiatan pembelajaran dan penilaian. Guru dapat menyusun sketsa pembelajaran tematik dengan bantuan tabel taksonomi. Hal ini dapat dilakukan dengan mengikuti langkah-langkah yang telah diterangkan pada bagian sebelumnya. Pada persiapan pembelajaran tematik dipadukan dengan penggunaan tabel taksonomi, maka kedua langkah (persiapan pembelajaran tematik dan penggunaan tabel taksonomi) harus dikolaborasikan. Kali ini cara yang digunakan adalah cara kedua, yakni menentukan tema terlebih dulu.

Pada contoh penggunaan tabel taksonomi ini, materi yang digunakan adalah materi kelas 2 SD.

1. Menentukan Tema

Dalam menentukan tema, guru sebelumnya bisa mendiskusikan dengan siswa atau rekan sesama guru. Tema yang ditentukan pada contoh ini adalah "tumbuhan".

2. Memilih Kompetensi Dasar

Setelah menentukan tema, guru menganalisis kompetensi dasar-kompetensi dasar yang sekiranya berkaitan dengan tema tersebut. Sehubungan dengan tema "tumbuhan" kompetensi dasar yang dipilih sebagai berikut:

IPA: mengenal bagian utama tumbuhan di sekitar rumah dan sekolah melalui pengamatan.

Bhs Indonesia: mendeskripsikan tumbuhan di sekitar sesuai ciri-cirinya dengan kalimat yang mudah dipahami orang lain.

SBK: membuat cat pewarna dari bahan buatan yang aman.

3. Menyusun Jaring Tema

Gambarkan ketiga KD yang dipilih dalam sebuah jaring-jaring dengan tujuan untuk melihat/memperjelas kaitan KD tiap mapel dengan tema yang ditentukan.

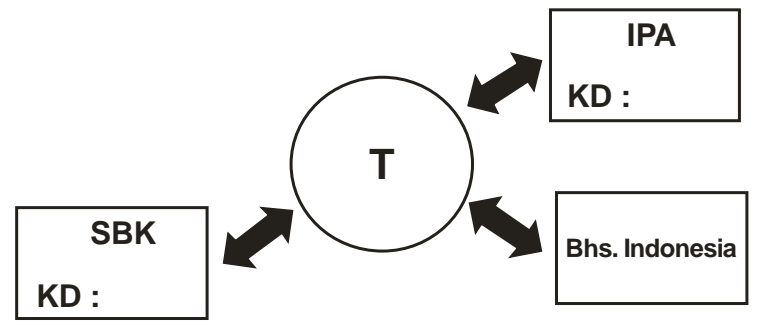

Gambar 3. Diagram Pembelajaran Tematik dengan Tema "Tumbuhan"

4. Merumuskan Tujuan Pembelajaran dan Meletakkannya pada Tabel Taksonomi. Bisa dikatakan tujuan pembelajaran adalah pernyataan yang mendeskripsikan hasil akhir yang diharapkan dari proses pembelajaran. Jika membicarakan mengenai tujuan pembelajaran maka erat kaitannya dengan pertanyaan "Apa yang akan siswa pelajari dari aktivitas pembelajaran ini?" Sebelum merumuskan tujuan pembelajaran, guru hendaknya menentukan aspek dimensi 
proses kognitif yang akan ditekankan untuk dikuasai siswa. Apakah akan menekankan pada penguasaan pemahaman siswa, kemampuan analisis siswa, kemampuan mengevaluasi siswa, atau pada tingkat yang lainnya. Pada pembelajaran dengan tema "tumbuhan" ini akan ditekankan pada penguasaan ingatan faktual terhadap struktur bagian utama tumbuhan, kemampuan mengklasifikasikan, serta kemampuan mencipta siswa. Sehingga bila dituliskan pada tabel taksonomi akan terlihat seperti pada tabel 5.

Pada tabel 5, tujuan pertama, mengidentifikasi merupakan salah satu kategori dalam proses kognitif mengenali, sehingga diletakkan pada proses kognitif mengingat. Dari segi pengetahuan, kata kerja mengidentifikasi diikuti dengan kata benda bagian-bagian tumbuhan menunjukkan suatu pengetahuan yang berkaitan dengan detail-detail elemen-elemen yang spesifik, sehingga termasuk dalam ranah pengetahuan faktual, maka tujuan pertama diletakkan pada sel A1. Tujuan kedua, mengklasifikasikan berkaitan dengan menentukan sesuatu dalam satu kategori, sehingga masuk dalam proses kognitif memahami. Dari segi pengetahuan, kegiatan mengklasifikasikan membutuhkan pengetahuan tentang klasifikasi dan kategori, sehingga termasuk dalam kategori pengetahuan konseptual, maka tujuan kedua diletakkan pada sel B2. Begitu pula tujuan ketiga sampai tujuan keenam, untuk menentukan letaknya pada tabel taksonomi Bloom perlu dianalisis berdasarkan jenis dimensi proses kognitif dan dimensi pengetahuannya (lihat tabel 1 dan 2). Sehingga diperoleh: tujuan ketiga terletak pada selA3,

Tabel 4. Matrik Pembelajaran Tematik dengan Tabel Taksonomi Bloom

\begin{tabular}{|c|c|c|}
\hline $\begin{array}{c}\text { Persiapan Pembelajaran } \\
\text { Tematik }\end{array}$ & $\begin{array}{l}\text { Penggunaan Tabel } \\
\text { Taksonomi }\end{array}$ & $\begin{array}{c}\text { (Pembelajaran Tematik + } \\
\text { Tabel Taksonomi) }\end{array}$ \\
\hline a. Menentukan tema & & a. Menentukan tema \\
\hline b. Memilih KD/indikator & & $\begin{array}{l}\text { b. Memilih KD/ indikator yang } \\
\text { sesuai }\end{array}$ \\
\hline \multirow[t]{4}{*}{ c. Menyusun jaring tema } & & c. Menyusun jaring tema \\
\hline & $\begin{array}{l}\text { a. Rumuskan tujuan } \\
\text { pembelajaran } \\
\text { b. Letakkan tujuan } \\
\text { pembelajaran pada tabel } \\
\text { taksonomi sesuai dengan } \\
\text { kategorinya }\end{array}$ & $\begin{array}{l}\text { d. Merumuskan tujuan } \\
\text { pembelajaran dengan } \\
\text { meletakkannya pada tabel } \\
\text { taksonomi }\end{array}$ \\
\hline & $\begin{array}{l}\text { c. Rumuskan kegiatan } \\
\text { pembelajaran yang akan } \\
\text { dilakukan untuk } \\
\text { mencapai tujuan } \\
\text { pembelajaran }\end{array}$ & $\begin{array}{l}\text { e. Menuliskan kegiatan } \\
\text { pembelajaran pada tabel } \\
\text { taksonomi }\end{array}$ \\
\hline & $\begin{array}{l}\text { d. Rumuskan asesmen yang } \\
\text { selaras dengan tujuan } \\
\text { pembelajaran }\end{array}$ & $\begin{array}{l}\text { f. Menuliskan penilaian/ } \\
\text { asesmen pada tabel } \\
\text { taksonomi }\end{array}$ \\
\hline $\begin{array}{l}\text { d. Membuat rancangan } \\
\text { pembelajaran }\end{array}$ & & $\begin{array}{l}\text { g. Menyusun rancangan } \\
\text { pembelajaran yang } \\
\text { lengkap }\end{array}$ \\
\hline
\end{tabular}


tujuan keempat pada sel B4, tujuan kelima pada sel C6, dan tujuan keenam pada sel C5.

5. Menuliskan Kegiatan Pembelajaran Langkah selanjutnya adalah menuliskan kegiatan pembelajaran berdasarkan tujuan yang telah dirumuskan. Kegiatan pembelajaran ini merupakan serangkaian aktivitas yang dilakukan siswa dalam rangka untuk mencapai tujuan pembelajaran. Dalam pembelajaran ini, dialokasikasn waktu selama 1 kali pertemuan (6 x 40 menit). Kegiatan pembelajaran dituliskan pada tabel taksonomi seperti pada tabel 6.

\section{Menentukan Asesmen atau Penilaian}

Sudah dikatakan diawal bahwa antara tujuan pembelajaran, kegiatan pembelajaran, dan penilaiannya harus selaras untuk mencapai pembelajaran yang baik. Jangan sampai terjadi masalah seperti misalnya guru merumuskan tujuan pembelajaran: menganalisis sebab terjadinya suatu peristiwa namun kemudian menguji siswanya dengan tes memori faktual. Asesmen di sini bisa berfungsi untuk mengetahui tingkat ketercapaian tujuan pembelajaran, atau bisa juga untuk acuan dalam memperbaiki proses kegiatan belajar selanjutnya. Dalam pembelajaran dengan tema "tumbuhan" ini penulis menerapkan asesmen seperti yang tampak pada tabel 7 .

Pada sel A1 digunakan asesmen A yaitu tes berbentuk isian, karena tujuan dari pembelajaran pada sel tersebut adalah berkaitan dengan aspek ingatan. Pada sel B2 digunakan asesmen $C$ yaitu berupa tes memasangkan karena sel tersebut berkaitan dengan kemampuan siswa dalam pengklasifikasian. Pada sel B1 digunakan asesmen $B$, yaitu berupa penilaian portofolio karena sel tersebut berkaitan dengan kemampuan siswa dalam menuliskan ciri-ciri tumbuhan dengan kalimat yang mudah dipahami. Dalam penilaian portofolio tersebut terdapat beberapa aspek yang dinilai berkaitan dengan keterampilan menulis siswa. Pada sel B4 menggunakan asesmen $D$ yaitu menggunakan penilaian tes berbentuk uraian karena sel tersebut

Tabel 5. Penggunaan Tabel Taksonomi Bloom Dua Dimensi

\begin{tabular}{|c|c|c|c|c|c|c|}
\hline $\begin{array}{c}\text { Dimensi } \\
\text { Pengetahuan }\end{array}$ & Mengingat & Memahami & $\begin{array}{c}\text { Menerap } \\
\text { kan }\end{array}$ & $\begin{array}{c}\text { Meng- } \\
\text { analisis }\end{array}$ & $\begin{array}{c}\text { Meng- } \\
\text { evaluasi }\end{array}$ & Mencipta \\
\hline $\begin{array}{c}\text { Pengetahuan } \\
\text { Faktual }\end{array}$ & Tujuan 1 & & & & \\
\hline $\begin{array}{c}\text { Pengetahuan } \\
\text { Konseptual }\end{array}$ & Tujuan 3 & Tujuan 2 & & Tujuan 4 & & Tujuan 5 \\
\hline $\begin{array}{c}\text { Pengetahuan } \\
\text { Prosedural }\end{array}$ & & & & & Tujuan 6 & T. \\
\hline $\begin{array}{c}\text { Pengetahuan } \\
\text { Metakognitif }\end{array}$ & & & & & & \\
\hline
\end{tabular}

Keterangan:

Tujuan 1 : Siswa dapat mengidentifikasi bagian-bagian tumbuhan

Tujuan 2 : Siswa dapat mengklasifikasikan jenis-jenis tumbuhan

Tujuan 3 : Siswa dapat mendeskripsikan tumbuhan sesuai ciri-cirinya dengan kalimat yang mudah dipahami orang lain

Tujuan 4 : Siswa dapat memilih bahan alami untuk membuat pewarna

Tujuan 5 : Siswa dapat membuat cat pewarna dari bahan yang aman

Tujuan 6 : Siswa dapat menguji coba hasil cat pewarna yang dibuat 
berkenaan dengan kemampuan siswa dalam menganalisis. Pada sel C6 digunakan asesmen $F$ yaitu penilaian unjuk kerja, di mana penilaian dilakukan ketika kegiatan pembelajaran berlangsung. Penilaian dilakukan untuk menilai proses siswa dalam membuat cat pewarna alami. Pada sel C5 digunakan asesmen $E$ yaitu penilaian produk. Pada penilaian produk ini, cat warna yang dibuat siswa dinilai setelah cat warna tersebut diaplikasikan dalam gambar.

\section{Pembelajaran Bermakna}

Pengetahuan merupakan salah satu elemen penting dalam belajar. Ini adalah pandangan yang wajar dalam pembelajaran yang memiliki implikasi terhadap bagaimana mengajar-seperti menampilkan informasi kepada peserta didik dalam buku-buku dan ceramah-dan bagaimana menilai-seperti tes untuk melihat berapa banyak materi yang disampaikan dapat ingat siswa (Mayer, 2001).
Perolehan pengetahuan bukanlah unsur utama pada visi yang lebih luas dari pembelajaran melainkan pengetahuan tersebut dapat digunakan dalam berbagai situasi yang baru. Guru, kadang-kadang hanya terfokus pada satu jenis pengolahan kognitif dalam pengajaran dan penilaian yang sering kita sebut "mengingat". Gagasan bahwa pendidikan dapat diperluas untuk mencakup berbagai proses kognitif yang lebih lengkap adalah dasar utama pada taksonomi yang direvisi.

Dua tujuan pendidikan yang paling penting adalah untuk membantu retensi dan membantu transfer (yang ketika itu terjadi menunjukkan pembelajaran bermakna). Retensi adalah kemampuan untuk mengingat materi pada beberapa waktu kemudian dalam banyak cara yang sama yang ditampilkan selama pembelajaran. Transfer adalah kemampuan untuk menggunakan apa yang telah dipelajari untuk memecahkan masalah baru, menjawab pertanyaan-pertanyaan baru, atau memfasilitasi

Tabel 6. Penggunaan Tabel Taksonomi Bloom Dua Dimensi

\begin{tabular}{|c|c|c|c|c|c|c|}
\hline $\begin{array}{c}\text { Dimensi } \\
\text { Pengetahuan }\end{array}$ & Mengingat & Memahami & Menerapkan & Menganalisis & Mengevaluasi & Mencipta \\
\hline $\begin{array}{c}\text { Pengetahuan } \\
\text { Faktual }\end{array}$ & $\begin{array}{c}\text { Tujuan 1 } \\
\text { Aktivitas 1,2 }\end{array}$ & & & & & \\
\hline $\begin{array}{c}\text { Pengetahuan } \\
\text { Konseptual }\end{array}$ & $\begin{array}{c}\text { Tujuan 3 } \\
\text { Aktivitas 5,6 }\end{array}$ & $\begin{array}{c}\text { Tujuan 2 } \\
\text { Aktivitas 3,4 }\end{array}$ & & $\begin{array}{c}\text { Tujuan 4 } \\
\text { Aktivitas 7 }\end{array}$ & & \\
\hline $\begin{array}{c}\text { Pengetahuan } \\
\text { Prosedural }\end{array}$ & & & & $\begin{array}{c}\text { Tujuan 6 } \\
\text { Aktivitas 9 }\end{array}$ & $\begin{array}{c}\text { Tujuan 5 } \\
\text { Aktivitas 8 }\end{array}$ \\
\hline $\begin{array}{c}\text { Pengetahuan } \\
\text { Metakognitif }\end{array}$ & & & & & \\
\hline
\end{tabular}

Keterangan

Tujuan : (sama dengan tujuan yang tertulis pada keterangan tabel 5)

Aktivitas 1: Menyebutkan bagian-bagian utama tumbuhan berdasarkan gambar yang diamati

Aktivitas 2: Menyebutkan kegunaan bagian-bagian utama tumbuhan

Aktivitas 3: Mengelompokkan tumbuhan yang memiliki batang bercabang dan tidak bercabang

Aktivitas 4:Mengelompokkan buah yang termasuk berbiji satu dan berbiji banyak

Aktivitas 5: Menyebutkan ciri-ciri tumbuhan dengan kalimat yang mudah dipahami

Aktivitas 6: Menyimpulkan nama tumbuhan yang disebutkan ciri-cirinya

Aktivitas 7: Memilih bahan alami (dari tumbuhan) yang bisa digunakan membuat pewarna

Aktivitas 8: Membuat cat pewarna dari bahan alami (dari tumbuhan)

Aktivitas 9:Menggunakan cat warna yang dibuat untuk membuat gambar, kemudian 
pembelajaran materi pelajaran baru (Mayer \& Wittrock, 1996). Singkatnya, retensi mengharuskan siswa mengingat apa yang telah mereka pelajari, sedangkan transfer menuntut siswa tidak hanya mengingat tetapi juga untuk memahami dan dapat menggunakan apa yang telah mereka pelajari (Bransford, Brown, \& Cocking, 1999; Detterman \& Sternberg, 1993; Haskell, 2001; Mayer, 1995; McKeough, Lupart, \& Marini, 1995; Phye, 1997).

Menurut Bobbi DePorter (2000) pembelajaran bermakna dapat terjadi bila pembelajaran tersebut dilaksanakan secara menyenangkan dan mengubah energi peserta didik menjadi cahaya dan bermakna. Suparno (1997) menjelaskan pembelajaran bermakna adalah suatu proses pembelajaran di mana informasi baru dihubungkan dengan struktur pengertian yang sudah dipunyai seseorang yang sedang dalam proses pembelajaran. Proses belajar individual dan kontekstual, artinya proses belajar terjadi dalam diri individu sesuai dengan perkembangan dan lingkungannya.
Pembelajaran bermakna (meaningful learning) merupakan proses dikaitkannya informasi baru pada konsep-konsep relevan yang terdapat dalam struktur kognitif seseorang (Ausubel dalam Yamin, 2011). Arends juga menyebutkan bahwa pembelajaran berbasis masalah akan melahirkan suatu kebermaknaan karena ia sebagai landasan investigasi dan penyelidikan bagi peserta didik. Pembelajaran bermakna juga disebut sebagai hasil dari peristiwa pembelajaran yang ditandai oleh terjadinya hubungan antara aspek-aspek, konsep-konsep, informasi atau situasi baru dengan komponen-komponen yang relevan didalam struktur kognitif peserta didik.

Proses pembelajaran tidak sekedar menghafal konsep-konsep atau fakta-fakta belaka, tetapi merupakan kegiatan menghubungkan konsep-konsep untuk menghasilkan pemahaman yang utuh, sehingga konsep yang dipelajari akan dipahami secara baik dan tidak mudah dilupakan. Dengan demikian, agar terjadi belajar bermakna, maka pembelajar

Tabel 7. Penggunaan Tabel Taksonomi Bloom Dua Dimensi

\begin{tabular}{|c|c|c|c|c|c|c|}
\hline $\begin{array}{c}\text { Dimensi } \\
\text { Pengetahuan }\end{array}$ & Mengingat & Memahami & Menerapkan & Menganalisis & Mengevaluasi & Mencipta \\
\hline $\begin{array}{c}\text { Pengetahuan } \\
\text { Faktual }\end{array}$ & $\begin{array}{c}\text { Tujuan } 1 \\
\text { Aktivitas 1,2 } \\
\text { Asesmen A }\end{array}$ & & & & & \\
\hline $\begin{array}{c}\text { Pengetahuan } \\
\text { Konseptual }\end{array}$ & $\begin{array}{c}\text { Tujuan } 3 \\
\text { Aktivitas 5,6 } \\
\text { Asesmen B }\end{array}$ & $\begin{array}{c}\text { Tujuan } 2 \\
\text { Aktivitas } \\
3,4 \\
\text { Asesmen C }\end{array}$ & & $\begin{array}{c}\text { Tujuan } 4 \\
\text { Aktivitas } 7 \\
\text { Asesmen D }\end{array}$ & & \\
\hline $\begin{array}{c}\text { Pengetahuan } \\
\text { Prosedural }\end{array}$ & & & & & $\begin{array}{c}\text { Tujuan } 6 \\
\text { Aktivitas } 9 \\
\text { Asesmen E }\end{array}$ & $\begin{array}{c}\text { Tujuan } 5 \\
\text { Aktivitas } 8 \\
\text { Asesmen F } \\
\end{array}$ \\
\hline $\begin{array}{l}\text { Pengetahuan } \\
\text { Metakognitif }\end{array}$ & & & & & & \\
\hline
\end{tabular}

\section{Keterangan}

Tujuan : (sama dengan tujuan yang tertulis pada keterangan tabel 5)

Aktivitas : (sama dengan aktivitas yang tertulis pada keterangan tabel 6)

Asesmen A : Tes berbentu isian

Asesmen B : Penilaian portofolio (berupa penilaian keterampilan menulis)

Asesmen $\mathrm{C}$ : Tes memasangkan

Asesmen $\mathrm{D}:$ Tes Uraian

Asesmen E : Penilaian Produk

Asesmen F : Penilaian Unjuk Kerja 
harus selalu berusaha mengetahui dan mengenali konsep-konsep yang telah dimiliki peserta didik dan membantu memadukannya secara harmonis konsep-konsep tersebut dengan pengetahuan baru yang akan dibelajarkan.

Selanjutnya Ausubel menambahkan bahwa pembelajaran bermakna akan lebih mudah dipahami jika bahan itu berkaitan, seperti; ikhtisar, resume, rangkuman, ringkasan, bahan, dan peta. Peta konsep adalah bagan tentang kerterkaitan seluruh konsep secara terpadu/terorganisir (hirarkis, distributive/ menyebar). Jean Piaget (teori perkembangan kognitif) merupakan teori konflik sosiokognitif yang berkembang menjadi aliran konstruktivistik, pengetahuan anak banyak ditentukan oleh karsa individual, yaitu keaktivan peserta didik menginterpretasi dirinya terhadap dunia nyata melalui pengalaman-pengalaman baru dan berinteraksi sosial.

Ausubel berpendapat bahwa pembelajar harus mengembangkan potensi kognitif peserta didik melalui proses pembelajaran bermakna. Tingkat pemahaman dan penalaran anak akan lebih berarti manakala sudah dimulai sejak pendidikan dasar, peserta didik diajak beraktivitas dan dilibatkan langsung dalam proses pembelajaran serta banyak memberi kesempatan pada peserta didik untuk berperan aktif, peran pembelajaran berpusat pada peserta didik (student centred). Demikian pula pada tingkat pendidikan yang lebih tinggi, akan lebih efektif pembelajaran yang menghubungkan konsepkonsep, bagan-bagan, diagram-diagram yang bermakna. Kemudian pembelajaran seperti ini akan menciptakan kebermaknaan bagi peserta didik.

Fokus pada pembelajaran bermakna konsisten dengan pandangan belajar sebagai konstruksi pengetahuan di mana siswa berusaha untuk memahami pengalaman mereka. Dalam pembelajaran konstruktivistik, siswa terlibat dalam proses kognitif aktif, seperti memperhatikan masuknya informasi yang bersifat mental, mengorganisir masuknya informasi ada di pikiran ke dalam representasi yang koheren, dan mengintegrasikan masuknya informasi yang masuk dengan pengetahuan yang ada (Mayer, 1999).

Proses kognitif yang digunakan sebagai sarana terjadinya retensi dan transfer meliputi enam kategori-satu proses kognitif yang terkait erat dengan retensi (Mengingat) dan lima lainnya semakin terkait dengan transfer (Memahami, Menerapkan, Menganalisis, Mengevaluasi, dan Menciptakan).

Berdasarkan hasil penelaahan tujuan ilustratif tercantum dalam Taksonomi asli dan pemeriksaan sistem klasifikasi lainnya, terdapat 19 proses kognitif tertentu yang sesuai dalam enam kategori (tabel Jenis dan Subjenis Dimensi Proses Kognitif). Ke-19 proses kognitif dimaksudkan untuk saling melengkapi, bersama-sama digambarkan luas dan batas-batas dari enam kategori.

\section{KESIMPULAN}

Berdasarkan uraian di atas dapat disimpulkan bahwa pembelajaran bermakna (meaningful learning) merupakan proses dikaitkannya informasi baru pada konsepkonsep relevan yang terdapat dalam struktur kognitif seseorang. Proses pembelajaran tidak sekedar menghafal konsep-konsep atau faktafakta belaka, tetapi merupakan kegiatan menghubungkan konsep-konsep untuk menghasilkan pemahaman yang utuh, sehingga konsep yang dipelajari akan dipahami secara baik dan tidak mudah dilupakan. Pembelajaran bermakna dapat terjadi ketika siswa mampu memecahkan permasalahan dalam situasi baru dan belajar secara aktif, dimana terdapat 6 kategori proses kognitif didalamnya.

Pembelajaran tematik memungkinkan terjadinya pembelajaran bermakna. Pembelajaran tematik dimaksudkan agar pembelajaran lebih bermakna dan utuh. Pembelajaran tematik ini memiliki peran yang sangat penting 
dalam meningkatkan perhatian, aktivitas belajar, dan pemahaman siswa terhadap materi yang dipelajarinya, karena pembelajarannya lebih berpusat pada siswa, memberikan pengalaman langsung kepada siswa, pemisahan mata pelajaran tidak begitu jelas, menyajikan konsep dari berbagai mata pelajaran dalam suatu proses pembelajaran, bersifat fleksibel, hasil pembelajaran dapat berkembang sesuai dengan minat, dan kebutuhan siswa.

Pembelajaran tematik agar berhasil dengan baik perlu dilakukan dengan menempuh tahapan perencanaan, penerapan dan evaluasi. Pembelajaran tematik dengan karakteristiknya yang menempatkan siswa pada kedudukan yang sangat penting, dimana siswa menjadi pusat dalam kegiatan pembelajaran (student centered), siswa juga diberi kesempatan untuk belajar bagaimana belajar (learn how to learn) sehingga kegiatan pembelajaran menjadi sangat bermakna bagi siswa.

\section{DAFTAR PUSTAKA}

Hastomo, dan Anwar Senen. Model Pembelajaran Tematik SD Kelas I-III. http:// staff.uny.ac.id/sites/default/files/tmp/ MODEL\%20 PEMBELAJARAN $\% 20$ TEMATIK $\%$ 20SD $\%$ 20KELAS $\%$ 20I\%20-\%20III.pdf diakses tanggal 1 Agustus 2013.
Krathwohl, D. R. 2002. Theory Into Practice: A Revision of Bloom's Taxonomy: An Overview. Ohio: Collegege of Education, The Ohio Sate University. 2010. A Taxononomy For Lorring, Teaching, and Assessing: A Revision Of Blooms Taxonomy Of Educational Objectives (Agung Prihantono, Penerjemah). Jakarta: Pustaka Jaya.

Sukayati, dan Sri Wulandari. 2009. Modul Matematika SD Program BERMUTU. Pembelajaran Tematik di SD. Jogjakarta: Pusat Pengembangan dan Pemberdayaan Pendidik Tenaga Kependidikan Matematika.

Trianto. 2010. Mengembangkan Model Pembelajaran Tematik. Jakarta: Prestasi Pustaka.

Wikipedia. Taksonomi. http://id.wikipedia.org/ wiki/Taksonomi diakses tanggal $20 \mathrm{Juli}$ 2013.

Yamin, Martinis. 2011. Paradigma Baru Pembelajaran. Jakarta: Gaung Persada. 